解 説 特集：地球環境資源としての森林 *

\title{
東アジア地域の森林資源状沉 **
}

\author{
天 野 正 博 $* * *$
}

\section{I . はじめに}

東アシアの内，中国本土及び韓国の森林資源の現状について述べる。なお，中国の森林資源に ついては，とくに断っていない限り中国林業部調査規劃院主編「中国山地森林」をもとにしてい る。また，中国の主だった林業政策及び地域の事情について，福建省林業部の石応林氏，黒竜江 省林業部の李裕国氏に指導して頂いた。韓国の森林資源の状況については，韓国林業研究院の朴 賛雨氏から資料を提供して頂いた。

\section{II . 中国}

\section{1. 森林資源の現況}

中国の森林資源は図一 1 に示したように分布している。この森林の分布は 2 つの流れに分か れており,一つは東北部の大興安嶺から小興安嶺, 長白山にかけて分布する針葉樹と落葉広葉 樹の混交林地帯, 華北の落葉広葉樹林帯, 華中の落葉広葉樹と常緑広葉樹との混交林帯および 常緑広葉樹林帯，として華南の熱帯季節雨林帯へと続く流れである。もう一つはチベット高原 の東端に位置する高山性の針葉樹林，それより標高の低い部分の針葉樹と広葉樹の混交林帯と 落葉広葉樹林帯，雲貴高原の常緑広葉樹林帯，海岸部の熱帯季節雨林帯に至る流れである。 中国の森林面積は「World Resources 1986」では閉鎖林が12,500万ha，柾林が4,500万ha となっている。なお，1950年には8,892万haであったとされている（S. HADEN-GUESTら， 1956）ので, 中国の森林面積は着実に増加しているといえよう。森林の蓄積は95億 $\mathrm{m}^{3}$ であり， その $31.1 \%$ が黒竜江・吉林省に，24.6\%が雲南・四川省に分布している。森林の被覆率からみ ると, 台湾が $57.8 \%$ ，福建省が $48.5 \%$ と高い森林率を示している。この他 $30 \%$ 以上の所は黒竜 江, 汇西, 浙江, 広東, 湖南の 5 省である。

* Forest resources as our global environment 第33回森林計画学会春期シンポジム The 33rd symposium of the Japan Society of Forest Planning held at Nagoya University on April 6, 1991

** Masahiro AmANo : Forest resources in East Asia

*** 森林総合研究所関西支所 Kansai Res. Center, For. and Forest Prod. Res. Inst, Kyoto 612 


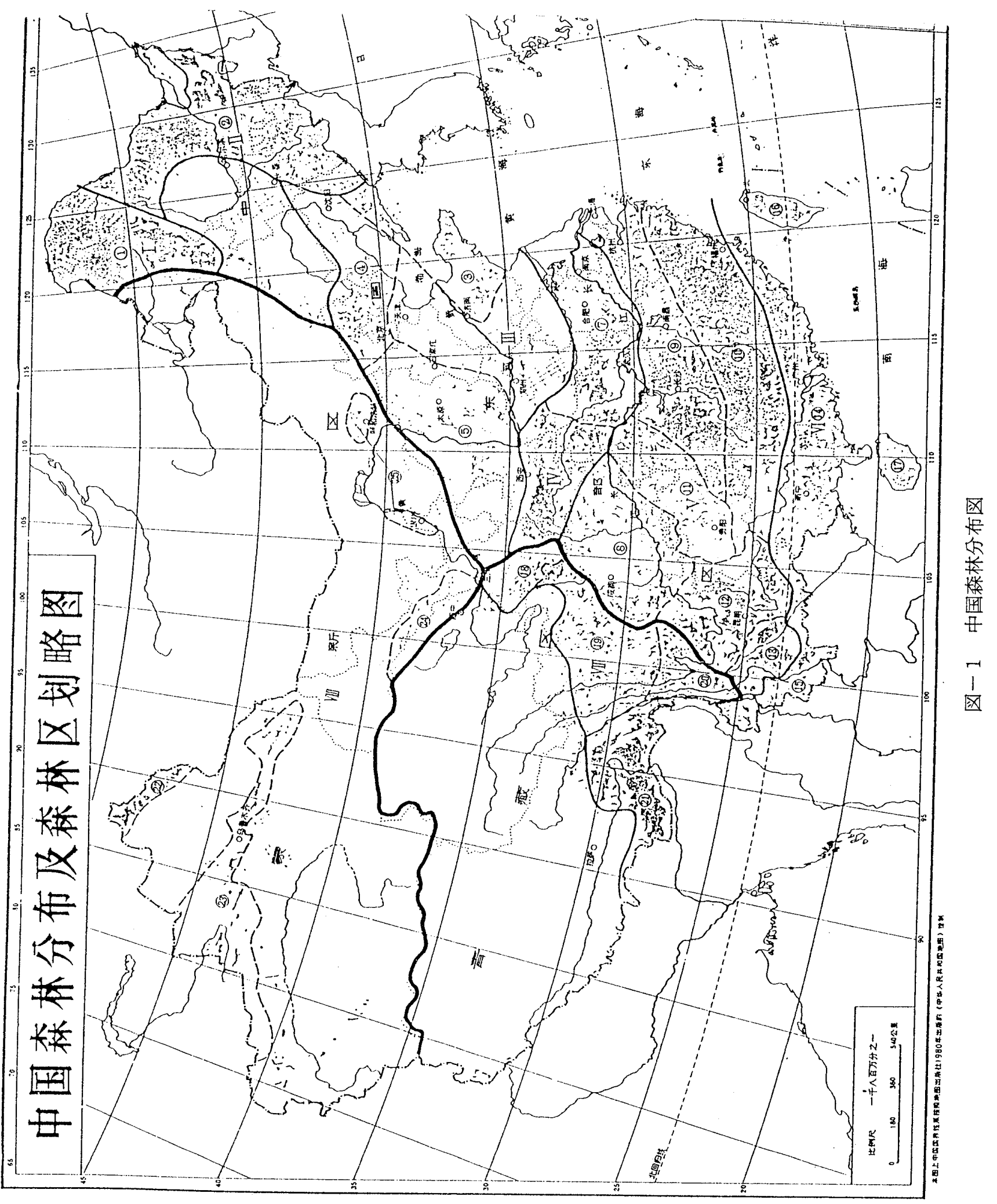




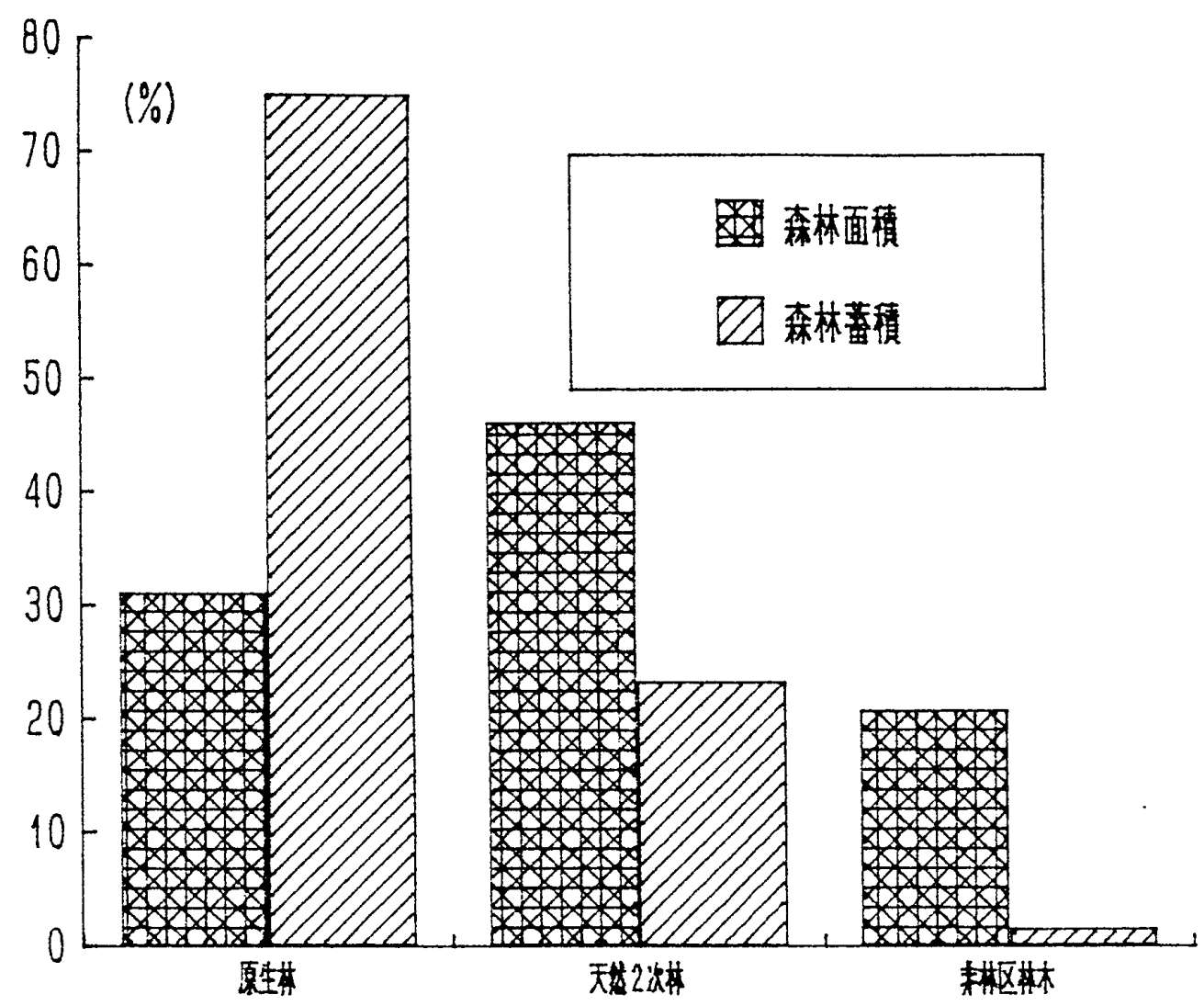

図一2 中国の森林タイプ別資源量

森林の適地の内，47\%は疎林や灌木林，無立木地である。また，蓄積が高い原生林は少なく， 多くは蓄積の少ない天然生 2 次林である。ちなみに原生林の面積は森林全体の $31.1 \%$ あるるが， 蓄積は75.1\%を占める。2 次林は面積で46.2\%，蓄積で23.3\%である（図－2）。原生林のha 当たり蓄積は $79 \mathrm{~m}^{3}$ である。

森林蓄積の内で用材林の蓄積は75億 $\mathrm{m}^{3}$ であり，このうち伐採可能な成熟林は 52 億 $\mathrm{m}^{3}$, 面積 では全国の用材林面積の32.1\%である。つぎに樹種別に蓄積をみると，針葉樹が $56.2 \% ，$ 広葉 樹が43.6\%である。用材林として重要な針葉樹の内訳を蓄積割合で拾いあげると,雲杉（Picea） 14.1\%,冷杉(Abies) 11.3\%,カラマッ (Larix) 10.1\%,雲南松(Pinus yunnanensis) $8.8 \%$ ，馬 尾松 (Pinus massomiana) 6.0\%，杉木 (Cunninghamia lanceolata) 2.5\%である。

つぎに中国の代表的な林業地域の幾つかについて，その資源状況をみてみる。

（1）大興安嶺

海抜 $1,100 \mathrm{~m}$ 前後であり，最高峰は $1,712 \mathrm{~m}$ である。年降水量は $350-500 \mathrm{~mm}$ と少ないが， 総雨量の70\%以上が 5〜8月に降る。樹種は興安落葉松(Larix gmelinii)が面積比で54.8\%， 白樺（Betura platyphylla）が23.6\%である。この他に樟子松（Pinus mongolica），紅皮雲 杉（Picea koraiensis）などがある。大興安嶺は起伏が大きく，高度によって森林植生は様々 な変化を示す。この地域の代表樹種である與安落葉松の収穫表を表一 1 に示す。 
Jpn. J. For. Plann. 17' 91

表 -1 興安落葉松の収擭表

（んaあたり）

\begin{tabular}{rrrrr}
\hline 林齡 & 樹高 & 直 径 & $\begin{array}{c}\text { 蓄積量 } \\
\text { 連 年 } \\
\text { 成長量 }\end{array}$ \\
\hline 10 & 3.2 & 2.0 & & \\
20 & 6.8 & 5.2 & 70 & \\
30 & 10.1 & 8.1 & 147 & 7.7 \\
40 & 13.1 & 10.8 & 213 & 6.6 \\
50 & 15.7 & 13.3 & 267 & 5.4 \\
60 & 18.2 & 15.9 & 314 & 4.7 \\
70 & 20.1 & 18.5 & 350 & 3.6 \\
80 & 21.7 & 20.8 & 378 & 2.8 \\
90 & 23.0 & 23.1 & 400 & 2.2 \\
100 & 24.2 & 25.2 & 418 & 1.8 \\
110 & 25.2 & 27.0 & 434 & 1.5 \\
120 & 26.0 & 28.5 & 446 & 1.2 \\
\hline \multicolumn{5}{c}{ 出典: 中国山地森林（1981） }
\end{tabular}

表一 2 小興安嶺の紅松収穫表

\begin{tabular}{|c|c|c|c|c|c|}
\hline & & \multicolumn{4}{|c|}{ （haあたり） } \\
\hline \multirow[t]{2}{*}{ 林龄 } & 平均 & 平均 & 本 数 & 蓄 積 & 成長量 \\
\hline & 直径 & 樹高。 & & & \\
\hline
\end{tabular}

\begin{tabular}{rrrrrr}
30 & 3.6 & 2.8 & 8065 & & \\
40 & 5.5 & 4.8 & 5746 & 44 & 1.1 \\
50 & 7.6 & 7.0 & 4234 & 86 & 1.7 \\
60 & 9.7 & 9.4 & 3156 & 137 & 2.3 \\
70 & 11.8 & 12.1 & 2374 & 196 & 2.8 \\
80 & 13.8 & 15.0 & 1834 & 257 & 3.2 \\
90 & 15.8 & 17.9 & 1471 & 323 & 3.6 \\
100 & 17.6 & 20.7 & 1224 & 387 & 3.9 \\
\hline
\end{tabular}

出典：中国山地森林（1981）

表一 3 黑竜江省における各樹種の伐期齢

\begin{tabular}{llll}
\hline \multicolumn{1}{c}{ 樹種 } & 人工林 & 天然林 \\
\hline 紅 & 松 & $>81$ 年 & $>121$ 年 \\
雲 & 杉 & $>81$ & $>121$ \\
落葉 松 & $>41$ & $>101$ \\
ハンノキ & $>21$ & \\
カン バ & $>41$ & $>61$ \\
ナ & ラ & $>51$ & $>81$ \\
\hline
\end{tabular}

(2) 小與安嶺

小興安嶺は黒竜江と松花江に囲まれ，森林率が54\%と高く，紅松 (Pimus koraiensis) のよ うな価值の高い経済樹種が多いのが特徵である。そして, 森林面積600万ha余のこの地域か ら全中国の木材生産量の $1 / 6 \sim 1 / 5$ を出している。年降水量も500-700 mm と大興安嶺 よりは恵まれている。標高 $300 \mathrm{~m}$ 以下の所は広葉樹林帯であり，300-650mの地域は広葉樹 と紅松の混交林帯になっている。650-1,000mでは雲杉，冷杉といった高山性の針葉樹帯で ある。1,000m以上では矮林となる。紅松の収穫表は表一2のよらである。

紅松の自然分布は東北部から日本の西岸, 朝鮮半島であり中心は長白山である。小興安嶺 を著名にしているのがこの紅松であり，この地域の蓄積の30\%を占める。つぎに多いのが雲 杉，冷杉で蓄積は11\%である。なお，黒竜江省における各樹種の伐期齢は表一 3 のようになっ ている。 
（3）蔂北東部山地

松花江を挟んで小與安嶺と対峙する形で長白山 $(2,744 \mathrm{~m})$ を最高峰とする東北東部山地 が位置している。行政的には吉林省に属し，降水量は500-900 $\mathrm{mm}$ 无あり，森林組成は小與 安嶺と似ている。この地域での人為的行為による植生の遷移は図一 3 のよらである。封山育 林とは菜炭材採取や放牧などでの林内への立ち入りを禁止し，育林途上での森林の消失を防 ごうというものである。

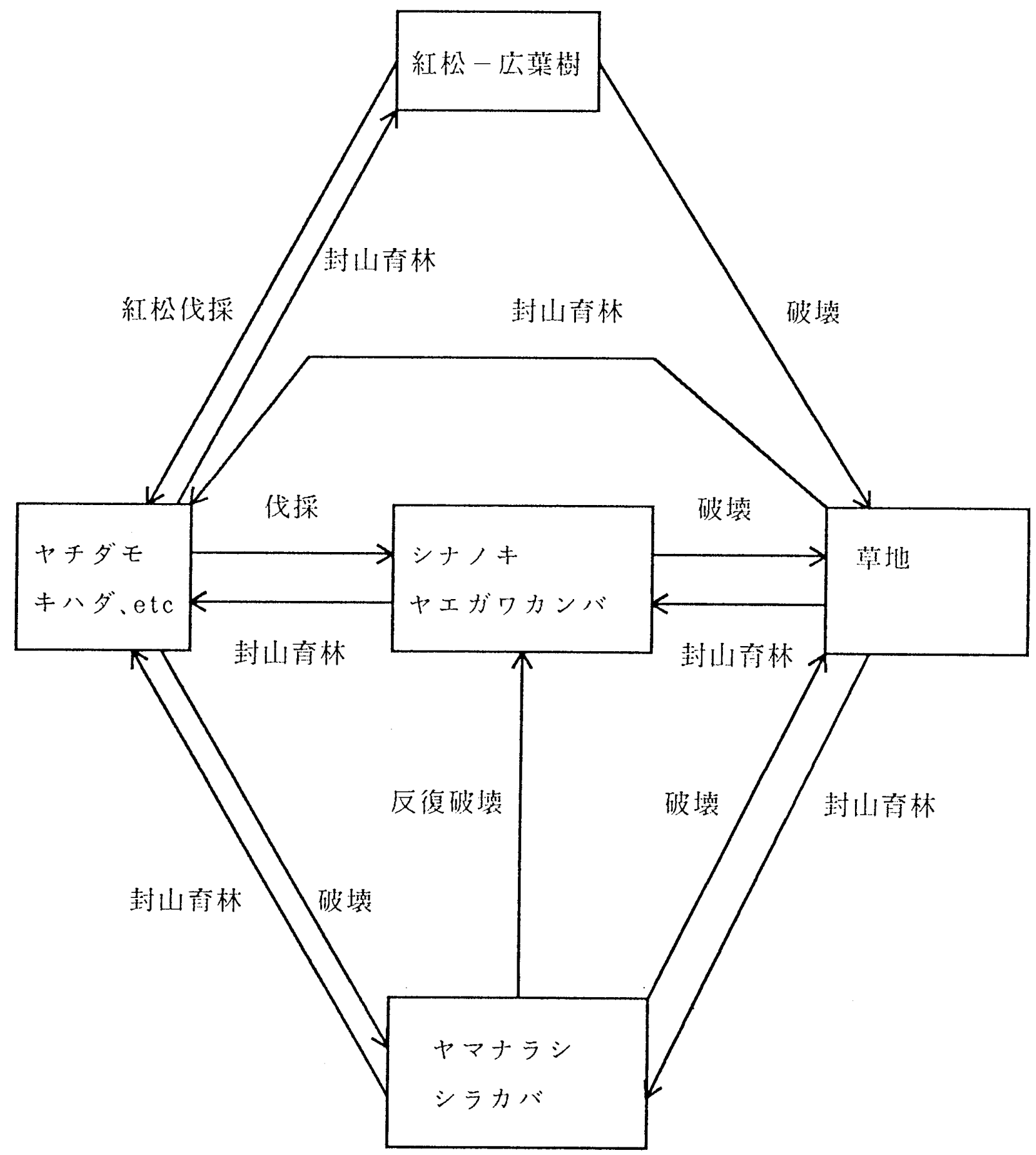

図一－＼cjkstart東北東部山地における人為覕乱による植生の遷移 
Jpn. J. For. Plann. $17^{\prime} 91$

\begin{tabular}{|c|c|c|c|c|c|c|c|}
\hline & \multirow{2}{*}{$\frac{\text { 森林面積 }}{\text { 幼 龄 林 }}$} & & 立: 万ha） & \multicolumn{2}{|c|}{ 表一 5} & \multicolumn{2}{|c|}{ 中国林業における福建省の位置 } \\
\hline & & 中齢林 & 成熟林 & & 森林 & 被覆率（\%) & 年伐採量 $\left(\right.$ 万 $\left.\mathrm{m}^{3}\right)$ \\
\hline 杉 木 & 34.19 & 18.3 & 4.09 & 1 & 台 & 湾 $(55.1)$ & 黒竜江(1315.17) \\
\hline 馬尾松 & 92.22 & 38.77 & 7.70 & 2 & 福 & 建 (37.0) & 内蒙古 $(626.44)$ \\
\hline 広葉樹 & 41.42 & 53.45 & 9.38 & 3 & 淅 & 江(33.7) & 吉 林( 685.69) \\
\hline 木麻黄 & 0.48 & & 0.72 & 4 & & 危江 (33.6) & 福 建( 546.12$)$ \\
\hline
\end{tabular}

表一 6 福建省の杉木材積表

\begin{tabular}{cccc}
\hline 林齢 & 平均直径 & 平均樹高 & 材積 \\
\hline 5 & 3.1 & 5.0 & 0.0024 \\
10 & 7.8 & 9.6 & 0.0206 \\
15 & 12.1 & 14.4 & 0.0800 \\
20 & 14.3 & 18.3 & 0.1460 \\
25 & 16.0 & 20.5 & 0.2149 \\
30 & 17.4 & 23.5 & 0.2845 \\
35 & 19.0 & 25.2 & 0.3398 \\
40 & 19.8 & 26.5 & 0.3843 \\
45 & 21.1 & 27.2 & 0.4255 \\
50 & 21.7 & 27.7 & 0.4513 \\
55 & 22.0 & 28.0 & 0.4698 \\
60 & 22.2 & 28.3 & 0.4895 \\
64 & 22.4 & 28.6 & 0.5043 \\
\hline 2 & & &
\end{tabular}

出典：福建南平渓后曹下杉木豊産林生長調査研究，1984

(4) 福建省

福建省の地形は「八山一水一分田」といわれるよ5に，その8 割は山岳地形である。気象 条件は, 年平均気温が $20^{\circ} \mathrm{C}$, 年間降水量は $1,100 \mathrm{~mm}$ から $2,000 \mathrm{~mm}$ であり, とくに内陸の山 岳部は $1,800 \mathrm{~mm}$ 以上の雨量があって，林業にとって好ましい気候にある。林業適地は 12 万 $\mathrm{k}$ $\mathrm{m}^{2}$ の省面積の内 $73 \%$ であが，半数近くが眯林や草地で用材林は林業適地の $51 \%$ にすぎな い。森林の蓄積は3億 9,000 万 $\mathrm{m}^{3}$ であるが，成長量と伐採量の比は $1: 1.2$ と過伐になってい る。主要樹種は杉木 (Cuminghamia lanceolata), 馬尾松 (Pinus massomiana) であり, 前者 は優良な建築用材であり後者は建築用材だけでなくパルプ用材，薪炭材として利用されてい る。福建省の用材林として利用される樹種の齢級別面積は表一 4 のようである。また, 
森林計画誌 17 '91

表一 5 に示したように森林被覆率では台泆の次に多いが，年伐採量からみると東北部の省が 上位を占め次が福建省になっている。但し，東北の各省は天然林資源からの伐採が多いのに 対し，福建省では高齢級の天然林は少なく人工林からの伐採が主体である。福建省の人工林

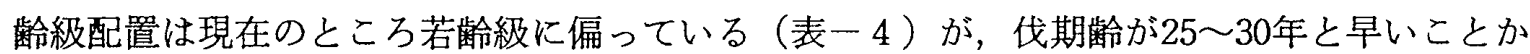
ら，今後は福建省の中国林業に占める地位は高まって行くものと推測される。

\section{2. 林業政策}

中国は20世紀末までに森林面積率を20\%にすることを目標に，これまで積極的に造林をして きた。まず，解放後はその組織力を活かして 3,000 万haの土地に造林を行ったが，專門技術の 不足，責任の不明確さ等により，多くの地域で失敗した。その後，反省を踏まえて新たな造林 計画が進められ，1950年代はじめには8.6\%にすぎなった森林率が1980年代には12.7\%になっ ている。第 7 次 5 ヶ年計画では2,770万haの造林により森林率を14\%に高めようとしている。 中国では各種政策を分かりやすいスローガンの形で国民に伝えているので，幾つかのキャッチ フレーズにしたがって林業政策の概要を紹介する。

(1) 三北防護林

「緑の長城」とも呼ばれ，華北地区，東北地区，西北地区の13,700万haの砂漠や不毛の 地において，水土の流出，風，砂嵐から農地や草地を護るため，黒竜汇省から中央アジアの 新彊に至る 12 省，自治区に6,000 k m の防風林を設定しようというものである。造林予定 面積は 2,300 万haであり，1984年には550万haの造林が終わり，成林率は $80 \%$ とされている。

（2）南部森林生産基地

東北諸省の天然林資源が減少しつつあることと，造林後の生育期間が長いことから，木材 の生産基地を将来は成長の早い南部にシフトさせようというものである。

(3) 四傍緑化

四傍とは集落の傍ら，川や水路の傍ら，路の傍ら，そして住宅の傍らをいい，中国を旅行 するときに各所でみられる並木は，この成果である場合が多く，森林の総蓄積の $2 \%$ 弱を占 める。樹種としては北部ではポプラ, 中央部ではキリ，南部ではユ一カリとモクマオウが多 W。

\section{3. 中国林業の問題点}

中国は絶対量としての森林資源は日本の $4 \sim 5$ 倍あるが，人口との対比でみれば，1人あた り森林面積は0.12ha，蓄積でみると $9 \mathrm{~m}^{3}$ （日本の場合は $0.21 \mathrm{ha}, 23 \mathrm{~m}^{3}$ ） と森林資源小国で ある。住宅での木材の使用は空枠やドア，床材，家具などに限られてはいるものの，紙パルプ も含めてその潜在需要は大きい。しかし，現在の森林は生産目的が不明確であったり，所有区 画や責任体制が暧昧であるため，必ずしも十分な保育が行われていない。また，四傍緑化のよ らに素晴らしい成功例の一方で，造林の成功率は50～70\%程度と推定され，さらに過伐に近い 木材生産をしている経営組織が多いことから，将来は木材の輸入量が増加すると予想される。 
Jpn. J. For. Plann. $17^{\prime} 91$

\section{III．韓国の森林資源の現状}

韓国は緯度としては日本とほ涪同じ位置にあるが，気候は大陸性傾向が強まり，年間降水量が $500-1,500 \mathrm{~mm}$ ，年平均気温は $5-14^{\circ} \mathrm{C}$ である。森林は国土の66\%，面積にして653万haである。 この地域の森林は早くからの文化の発達により繰り返し木材を伐採, 利用されてきたことから， 地力の減退が著しいため森林蓄積はhaあたり $31 \mathrm{~m}^{3}$ と低い。

\section{1 . 韓国の森林資源}

森林の所有形態は図一 4 に示したように私有林，公有林，国有林に分かれている。比率は日 本の場合と同じようなパターンをとっているが，私有林に対する規制はわが国に比べきつい。 森林の内容は $46 \%$ が針葉樹，27\%が広葉樹，そして残りが混交林であり，注ぼかが国の森林構 成と同じである。かっては国土のかなりの部分がはげ山と言われていたのが現在のよらな緑に 覆われるようになったのは，1973年から87年にかけて実施された第 1 次，第 2 次治山緑化事業 に負うところが大きい。このため，図一 5 に示したように森林の齢級構成は若龄級が多く成長 率が高い資源構成になっている。森林の平均蓄積は1979年には $17 \mathrm{~m}^{3} / \mathrm{ha}$ あっったのが， 1987年には31 $\mathrm{m}^{3}$ と着実に増加している。所有形態別にみると，奥地山岳地で交通不便なとこ ろにある国有林では $57 \mathrm{~m}^{3}$ ，公・私有林ではそれぞれ $29 \mathrm{~m}^{3}, 24 \mathrm{~m}^{3}$ である。

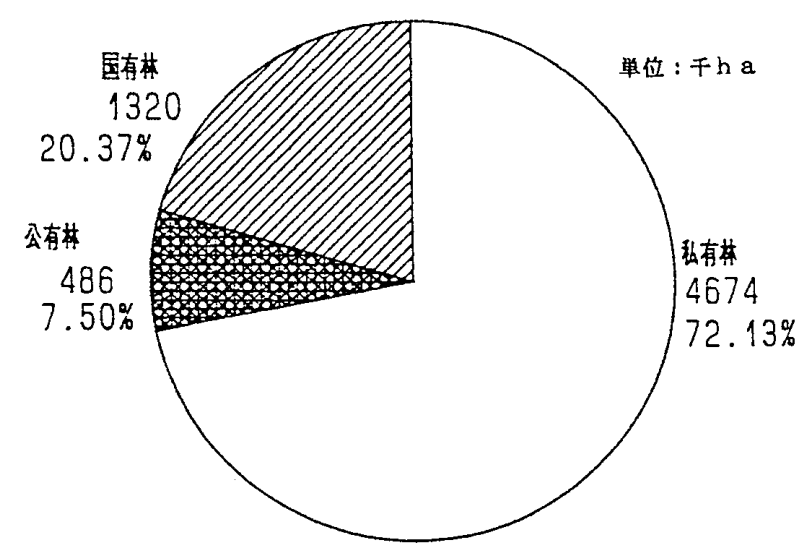

出典 : Forestry in Korestry Administration, Korea

図一 4 韓国の所有形態別森林面積 禹h

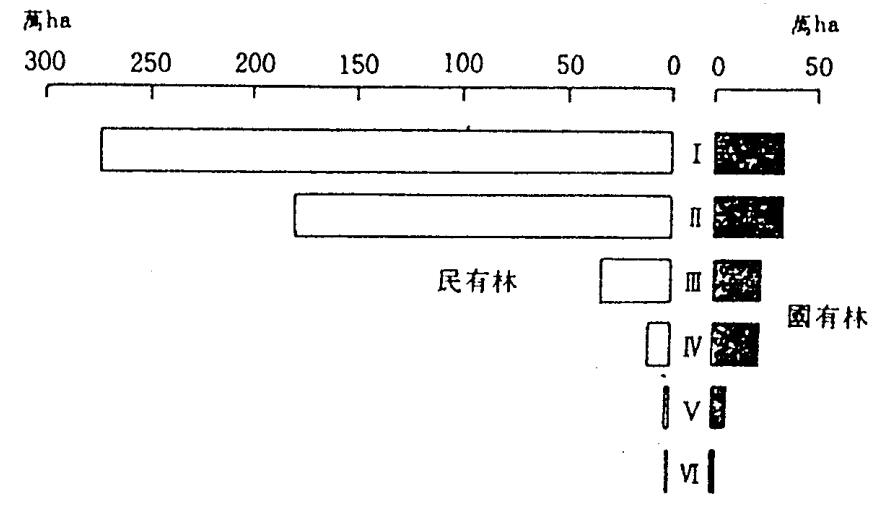

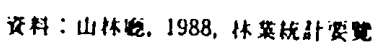

出典 : 韓国の山林と林業図説、䚌国山林庁

圀-5 踰級別森林面積 


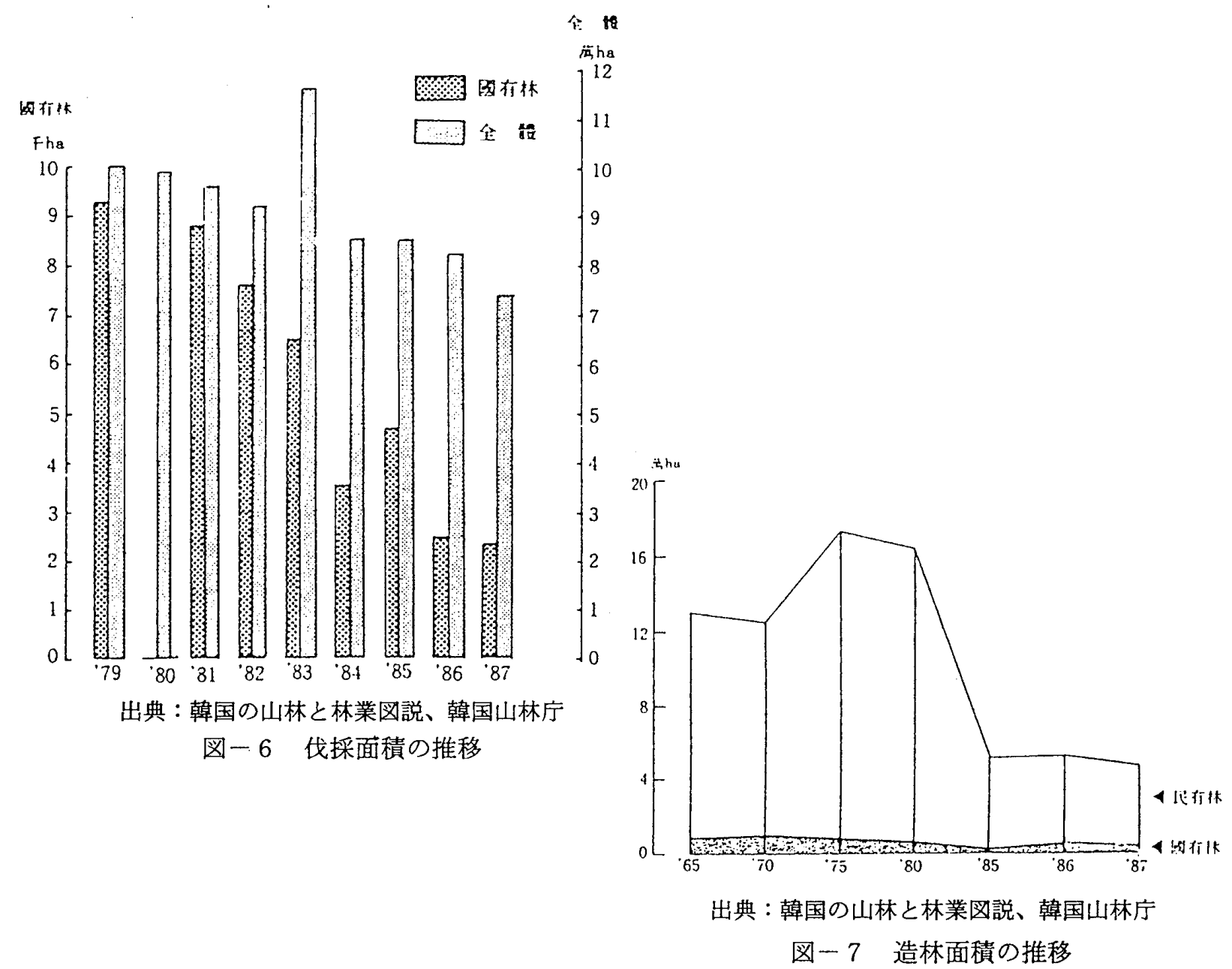

\section{2. 林業活動}

韓国では森林資源構成の現状からして木材の自給率はそれほど高くは望めない。1988年の総 需要量856万 $\mathrm{m}^{3}$ に対する自給率は15\%である。韓国では輸出を目的とした合板産業が興隆した 1970年前後から木材の海外への依存が高まり，自給率は70年で $21 \% ， 80$ 年で13\%であった。近 年, 輸出用の合板は新與輸出国の出現, 資源ナショナリズム等で激減したが, 国内の木材需要 が著しく伸びているため総需要量は堅調であり，現在も自給率は低いままである。

韓国林業は日本と同様に林業活動は沈滞傾向にあり，図一6，図一7に示すように伐採面積， 造林面積ともに減少しつつある。林家の所有目的を見ても $30 \mathrm{ha}$ 以上の大規模所有者では資源 増殖のためが過半数を占めるが，大多数を占める小規模所有者では, 無目的か墓地確保を所有 の目的としている場合が多い。

こうした韓国林業の停滞に対する危機感は林業界に強くあり, 図ー 8 に示すように森林の公 益的機能の経済的分析を行うなど，当面は森林の存在価值を木材生産以外でも積極的に評価し ていこらとの動きがある。韓国では国を挙げて緑化事業に取り組んだ歴史があるだけに，森林 の非木材生産機能に対する国民の理解も得やすいようである。 
Jpn. J. For. Plann. 17' 91

\section{単位：10 億ウォン}

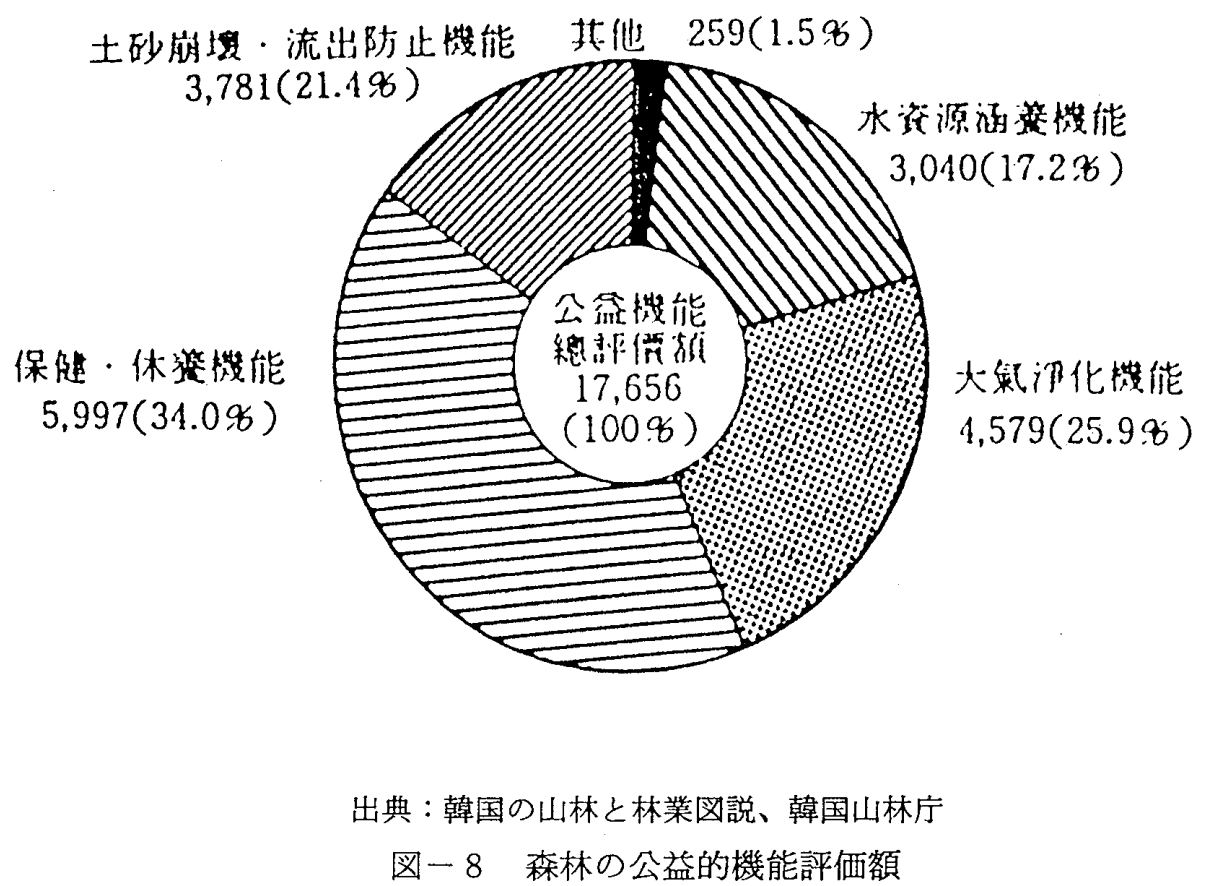

\section{3 . 韓国林業の問題点}

歴史的に繰り返されてきた森林からの木材収奪により，森林が成立している地域の土壌条件 はよくない。このため，国家プロシェクトとしての緑化事業は大きな成果を上げたものの，リ キーダマッなどの植栽による緑化目的での造林地が多い。これまでの植栽樹種では経済的価值 はそれほど高くないため，木材生産を目指した森林資源の造成はこれから始めようという段階 である。しかし，木材市況が低迷し，海外にも十分な木材資源が存在している今日，もう一度 新しい森林資源を造成することは容易ではない。日本ではとりあえず現存の林分を長伐期化に より将来価値ある資源にしようという方向をとっているが，韓国では経済樹種への転換をどう 図るかが大きな課題である。

\section{引用文献}

1) HAdEn-Guest, S., J. Wright and E. M. TecLAfF: World Geography of Forest Resources.

The World Press Company, New York, 1956

2）中国林業部調查規劃院主編：中国山地森林．中国林業出版社，北京，1981

3）林杰, 陳平留, 黄健儿：福建南平溪后曹下杉木豊産林生長調査研究. 福建林学院学報, 1984

4 ）海外林業コンサルタンツ協会：海外林業資源環境基礎調査（中国編）。日本木材備蓄機構，.1987

5) Forestry Administration, Republic of Canada : Forestry in Korea. 1987

6) EHRENREICH, John H. (野村勇 監訳)：中国の森林資源と林業(Forestry in Chaina訳)，農村文化社，1988 7) 山林庁：韓国の山林と林業図説. 山林庁，1989 